Revista Iberoamericana, Vol. LXXI, Núm. 210, Enero-Marzo 2005, 77-90

\title{
LA QUE MATA Y LA QUE MUERE POR SEGUNDA VEZ: ALGUNAS ESCENAS DEL IMAGINARIO AMENAZADO DEL PORFIRIATO ${ }^{1}$
}

\author{
POR \\ Adela Pineda Franco \\ Boston University
}

En este artículo elaboramos algunas reflexiones sobre la forma en que el crimen y la prostitución, la otra cara del imaginario porfiriano de "orden y progreso", se encarnan en la representación femenina. Innumerables trabajos han tocado el tema en el contexto finisecular europeo (Bernheimer; Dijkstra; Showalter), latinoamericano (Guy; Ludmer) y también mexicano (Buffington; Piccato), desde diversas disciplinas y enfoques. No pretendemos dilucidar una nueva hipótesis, únicamente presentamos una lectura basada en la yuxtaposición de varios discursos: los recuentos gráficos y criminológicos en torno a un asesinato pasional conocido como "el crimen de la calle de Tarrasquilla”, en el que María Villa, "La Chiquita”, dio muerte a Esperanza Gutiérrez, "La Malagueña”, ambas prostitutas, ${ }^{2}$ y dos novelas, La Rumba (1890-91) de Ángel de Campo, alias Micrós, y Santa (1903) de Federico Gamboa. Publicada por entregas siete años antes del suceso, la primera novela plantea la ambigua responsabilidad jurídica y social de un sujeto femenino a través de una irónica intertextualidad. En nuestra lectura de la segunda novela, sugerimos que María, la victimaria, y Esperanza, la víctima, se manifiestan en una sola figura, la de Santa, convirtiéndose en un mito del Porfiriato y, mediante su reproducción técnica, en el de generaciones subsecuentes.

Es pertinente resaltar que nuestra lectura no busca contrastar la realidad con la ficción. Nadie niega que un día de marzo del año de 1897 yacía el cadáver de Esperanza Gutiérrez en la morgue del hospital Juárez y que la acusada iba a pagar una sentencia de veinte años en la cárcel de Belén. Nadie niega que hubo un juicio y una serie de discursos que reconstruyeron los hechos y predijeron sus consecuencias. Sin embargo, no fueron los hechos, sino los discursos en torno a éstos los que les dieron sentido y "realidad" en el imaginario colectivo del Porfiriato. Son estos mismos discursos los que generaron su contrasentido y con ello las aporías del programa civilizador de “orden y progreso.” De hecho, a partir de las hipótesis de Jerome Bruner, Robert Buffington y Pablo Piccato estudian este caso con estrategias narratológicas y ponen de manifiesto el proceso de significación misma en el discurso positivista. Arguyen, con Anthony Giddens, que la

\footnotetext{
${ }^{1}$ Agradezco los lúcidos comentarios de Alberto Medina y Fabián Torres quienes leyeron este trabajo. ${ }^{2}$ El delito fue cubierto de manera sensacionalista en numerosos diarios, como El Foro, El Gráfico y El Imparcial. Consultar Buffington y Piccato para una reconstrucción del mismo.
} 
incesante búsqueda de evidencias, característica de la modernidad, conduce irreversiblemente a las fracturas y los vacíos del sentido.

Más que el contraste entre ficción y realidad, nos intriga su indisoluble interrelación. Lo que nos atañe aquí es la "literariedad” del positivismo y la máscara positivista de la literatura, o de qué manera podemos leer literatura a la luz del discurso público y viceversa. También nos interesa explorar la manera en que se resucita la muerte con el fin de aniquilarla una segunda vez en nombre del arte y de la civilización. María, Esperanza, Remedios y Santa: ¿cuál de todas pervive en la memoria colectiva y por qué? ¿Cuál es la operación que restituye el “desastre” nacional (la desviación, la degeneración, el crimen, la prostitución), integrándolo al orden del progreso, y cuál es el papel de la nostalgia y lo sentimental en esta restitución? Son estas preguntas las que servirán de guía a nuestro análisis.

\section{Los ANTECEDENTES DE LA MUJER CAÍDA}

En 1903, año de la publicación de Santa, el criminólogo Carlos Roumagnac visitaba a María Villa en la cárcel de Belén, con el fin de explicar su identidad criminal y al mismo tiempo asegurar su paulatina regeneración. Según Buffington y Piccato (408), la lógica criminológica del texto de Roumagnac se basa en una función narrativa: la de explicar los "estados intencionales" del comportamiento criminal. Influenciada por saberes evolucionistas, la criminología mexicana definía la degeneración social partiendo de orígenes somáticos y de transmisión hereditaria, o la subordinaba, de manera contradictoria, a las características del medio físico y social, y a ciertas categorías de raza, clase y género. ${ }^{3}$ En efecto, el perfil de María hecho por Roumagnac, como todos los otros que incluye en su libro Los criminales en México (1904), presenta una estructura acorde a esta ideología criminológica: la biografía como una secuencia de patologías y el testimonio como una prueba de su arrepentimiento y posible regeneración en la institución carcelaria. Dichos esquemas también constituían la base del relato naturalista-realista. Tanto Micrós como Gamboa les confieren a sus personajes femeninos un pasado verificable que explique su futuro comportamiento. En la sangre de Santa, había "gérmenes de muy vieja lascivia de algún tatarabuelo que en ella resucitaba con vicios y todo" (758), y en el cuerpo de Remedios “daba lástima ver ... los moretones, rastros de cólera brutal del herrero”, su padre alcohólico (187).

Para inferir que el crimen de Villa había sido inevitable, Roumagnac desplegaba su historia clínica. Sin embargo, las respuestas particulares de María no resultaban suficientemente prototípicas; es decir, no permitían situarla dentro de ciertas patologías y grupos sociales bien identificados por la “ciencia” criminológica. ${ }^{4}$ De aquí que el

\footnotetext{
${ }^{3}$ Dichas tesis se perciben en los estudios de principios de siglo citados en la bibliografía del mencionado Roumagnac, de Julio Guerrero, y de Luis Lara y Pardo.

${ }^{4}$ Según Buffington y Piccato (409), el alcoholismo y la epilepsia, claros indicadores de familias delictivas en la ideología de la criminología, no caracterizaban a la de María (409). No obstante, Roumagnac se esforzaba por agotar todas y cada una de las "patologías" que habían aquejado a la familia y al propio cuerpo de María, resaltando la tuberculosis. Asimismo María no había sido testigo de promiscuidad familiar pese a su pobreza, ni de relajación moral, pese a su educación católica (Roumagnac 105-106).
} 
método deductivo de Roumagnac no cuadrara del todo con la práctica inductiva de su empirismo. En Santa y en La rumba, la hipótesis científica tampoco se sostiene, principalmente porque, como bien ha observado Josefina Ludmer para el caso de Santa, esta perspectiva también introduce el problema de la responsabilidad del sujeto ante la ley y ante la sociedad (“Una lectura” 206).

\section{EL SUJETO FEMENINO Y LA RESPONSABILIDAD SOCIAL Y LEGAL}

En La rumba, la responsabilidad social de Remedios está asociada a su infracción de ciertas convenciones de clase y género. La explicación de su conducta desviada en base al determinismo se complica porque, al parecer, Remedios es quien se propone superar el medio y la herencia. Masculinizada por el narrador -“decíanle la Tejona por sus modales broncos” (193)-la desviación de Remedios ya se perfila en su ambición por salir de la vida de barrio -"Yo he de ser como las rotas" (195) - y en su voluntad para cancelar el abuso del padre ebrio, cuyos puñetazos Remedios, "hosca, feroz, intratable ... paraba como un maestro de pugilato” (194). En los bordes de la ideología porfiriana, la protagonista se manifiesta como la ficción de un "sujeto-posición diferente”; es decir, su historia está en “correlación con coyunturas de ruptura del poder doméstico" (Ludmer, “Mujeres” 793). ${ }^{5}$ Esto se evidencia durante el juicio de Remedios, en el que afloran las diversas versiones, no de los hechos, sino del deber-ser mujer: "las mujeres no han nacido para las aulas .... Un hombre ... le promete un hogar, y ella lo rechaza porque es un tendero” (328).

A partir de un sustrato ideológico positivista, Roumagnac identifica la caída de María con el rechazo hacia sus "protectores", pese a que dichos sujetos fueran asimismo violadores de la ley: el primero (el hijo del patrón) la hizo su querida a los trece años y el segundo (su primer amante en el burdel) le disparó con intención de matarla por infiel (105-107). La serialización de la narrativa de Roumagnac que postula la creciente degeneración de Villa (amante, alcohólica, prostituta, morfinómana, asesina) nos recuerda la de Gamboa en Santa; ésta también pasa por diversos espacios e instituciones en su camino hacia la degradación y también rompe con sus protectores (Rubio y el Jarameño). Desde la perspectiva del criminólogo, el rechazo a la protección patriarcal solo confirma la degradación moral de los personajes, pero, desde la de Santa, Remedios o María, la serie de rupturas con su consecuente desenlace tendría que constituir una reivindicación de justicia social y sexual, aunque fuera más allá de la ley. ${ }^{6}$ Es el relato en torno a María en el que se percibe este tipo de justicia.

\footnotetext{
${ }^{5}$ Para el caso europeo, véanse Showalter y Dijkstra quienes también establecen una correlación entre el ingreso de las mujeres a la esfera pública y las representaciones tremendistas, catastróficas o lésbicas del arte patriarcal. En el contexto del Porfiriato, Jean Franco documenta los casos de mujeres que históricamente confrontaron los patrones de la domesticidad femenina (100).

${ }^{6}$ Ludmer considera que el sentido de la justicia estatal varía desde donde se mire. Las películas de Almodóvar son ejemplos donde la que mata elude la justicia estatal porque hace justicia política y sexual ("Mujeres” 795).
} 
En una hoja volante de amplia circulación popular, el ilustrador José Guadalupe Posada presentó el delito de Villa en base a la primera declaración de ésta. ${ }^{7}$ Al momento de ser aprehendida, la detenida esgrimió una defensa excepcional al recurrir a los atenuantes de la ley pero subvirtiendo los códigos de clase y género. Según la recopilación periodística que del caso hicieron Buffington y Piccato, María había declarado inicialmente que había matado a Esperanza en un duelo para restituir su honor, vilipendiado por Esperanza al entablar relaciones sexuales con su amante, un hombre de clase más alta llamado Salvador Ortigoza. De la hoja volante, estos historiadores infieren la inversión de los códigos tradicionales de género y clase en materia de duelo y honor. María usurpa, mediante la postura (erguida, con las manos en ángulo recto, la una pegada al cuerpo y la otra apuntando con certeza), el lugar del duelista masculino y, mediante el atuendo (vestido negro de calle y peinado recogido), el de la mujer de la clase decente. La escena no se lleva a cabo en un lugar parecido a "la Rumba”, el barrio de Remedios, entorno naturalizado de la clase delictiva, sino en el espacio privado de un hogar burgués, en el que la duelista irrumpe desde el espacio público para hacerse justicia. Esperanza, de blanco, pero del blanco lívido de la mujer muerta, muestra su obscenidad con la pose de la que cae (literalmente el cuerpo, al impacto de bala, se precipita hacia atrás) y con el atuendo de la adúltera (camisón y pelo suelto). Dado que ni las mujeres practicaban duelos, ni era admisible que una prostituta sintiera amor o tuviera honor, la argucia de María no sólo complicaba la cuestión de su responsabilidad ante la ley, sino que develaba la relatividad de la ley misma al no proporcionarle los atenuantes de la justicia, con lo cual María se exponía a ser objeto de su extremo rigor.

De aquí que la acusada haya cambiado su versión durante el juicio, argumentando demencia, debilidad, fatalidad (la pistola se había disparado por accidente) y desconocimiento de la víctima, con el fin de gesticular la vulnerabilidad femenina de las narrativas finiseculares en torno a los crímenes pasionales y así ganarse el perdón de sus espectadores (Buffington y Piccato 399). ${ }^{8}$ De hecho ésta es la defensa que sostiene Remedios en La Rumba: “... yo que le había de quitar la pistola y el que no, hasta que se resbaló, yo me caí con él y se salió el tiro; después no le doy a usted razón, porque me puse

\footnotetext{
${ }^{7}$ Estas hojas volantes de la casa de Antonio Vanegas Arroyo eran parte del periodismo popular, "de a centavo", que se concentraba en la noticia sensacionalista. Speckman las describe como hojas de colores, con llamativos encabezados, con ilustraciones (hechas por Manuel Manilla y José Guadalupe Posada), que en ocasiones incluían corridos, y que se vendían en plazas, ferias o mercados. Dieron noticia de hechos milagrosos y de crímenes célebres como los de "El Chalequero”, "El Tigre de Santa Julia” y "La Chiquita.” Aclaramos que no podemos dar la paginación de las referencias a Speckman dado que consultamos la versión inédita del artículo citado en la bibliografía, recientemente publicado. La hoja volante fue consultada en la reproducción de Roberto Berdecio y Stanley Appelbaum, 38. Nuestra lectura se apoya en la de Buffington y Piccato (404-406).

${ }^{8}$ La literatura sobre crímenes pasionales era tema de la "alta" literatura (en sus registros naturalistas y decadentistas), particularmente en su versión francesa, y circulaba en las revistas de la época, pero también lo era de la prensa popular. Una segunda hoja volante de Posada muestra, con intención didáctica, el castigo de María vía lo sobrenatural, al representarla en la cárcel, atormentada por el fantasma de Esperanza (esta hoja volante también es aludida por Buffington y Piccato. Consultamos la reproducción en Tyler 82).
} 
como loca ...” (315). Sorprende la “feminidad” de esta confesión cuando se contrasta con las ya referidas actitudes masculinas de Remedios, alias “la Tejona”. Tal contradicción podría ser interpretada, por inferencia, como una estrategia similar a la que se detecta en Villa para burlar la justicia a través de la imitación de los signos femeninos (pasión, pasividad, locura). Las que matan, señala Ludmer, actúan estos signos para hacerse agentes de una justicia que va más allá del Estado (“Mujeres” 795).

No obstante, si pasáramos por alto esta contradicción y nuestra lectura de la novela fuera consecuente con el cuadro de los primeros capítulos en los que Remedios deja el hogar para caer en brazos del seductor barcelonette iniciando su descenso moral, tendríamos que buscar un desenlace consecuente: la muerte del seductor y la responsabilidad moral y social de Remedios, pero no la legal (de hecho, Remedios es declarada inocente), para evitar ambigüedades e ironías como en el caso de Villa; a ésta ninguna estrategia de defensa le valió la absolución. ${ }^{9}$ Por otra parte, la no-responsabilidad legal del sujeto con la argucia del “accidente” (la pistola se disparó) podría ser entendida como la fatalidad típica del determinismo del que nunca escapan los personajes naturalistas. Sin embargo, Micrós sugiere otra interpretación al momento de reconfigurar la escena del crimen y presentar la evaluación legal, moral y social de Remedios; en este momento, la anécdota determinista se trastoca con una incursión en el "carnaval democrático de la modernidad”. ${ }^{10}$

\section{La JUSTICIA COMO ESPECTÁCULO}

En un gesto casi brechtiano, el narrador de La Rumba sugiere la calidad artificiosa del juicio de Remedios y de su propia escritura: "No he conocido los detalles del crimen o desgracia (vamos a ver qué sale)...” (281). Dada la imposibilidad de explicar lo que se desconoce, sólo queda asistir al espectáculo de su reproducción, un espectáculo en el que la suerte se disfraza de justicia o viceversa, y los espectadores ríen sin querer y lloran sin saber por qué. A partir del episodio del crimen, el determinismo biológico o social se manifiesta en la novela como una invención masculina, y Remedios como una figura cultural saturada de sentidos en torno al deber-ser mujer y al querer-ver a la mujer. La conversión, de personaje “de carne y hueso" a figura "textual”, se evidencia claramente en la siguiente cita:

Remedios, tú querías hacerte notable ... pues has conseguido tu deseo ... en un segundo, tu nombre ha recorrido el espacio que separa la mesa de un gacetillero de ese monstruo que te fascinaba: la sociedad .... Tienes ya tu lugar en la gran comedia humana, y el público ha leído con avidez ese capítulo cuya trama -esa trama vulgar de todas las tragedias-fue el amor, y cuyo desenlace ya presienten los filósofos inéditos de La Rumba. (280)

\footnotetext{
${ }^{9}$ María recibió la condena de veinte años, la máxima para una mujer durante el Porfiriato (Buffington y Piccato 401). En la cárcel, sostuvo una hegemonía considerable entre presos y celadores (Roumagnac 113).

${ }^{10}$ Tomo la frase en alusión a uno de los capítulos del libro de Ángel Rama, Las máscaras democráticas del modernismo.
} 
La crítica de Micrós se dirige primero a la prensa amarillista, morbosa, de a centavo, ejemplificada en la cobertura de El Noticioso y en Lucas Rebolledo, personaje que representa a esa emergente figura del periodismo industrial, el cazador de noticias, conocido entonces bajo el anglicismo de repórter. No obstante, Micrós también alude a la prensa modernizada y de gran tiraje con el recuento de El Imparcial, el periódico representativo de la "no-política" de la política porfiriana. A El Imparcial, Micrós le otorga el privilegio positivista de la objetividad con una prosa escueta, breve y sin gran adjetivación, pero al mismo tiempo lo desautoriza, neutralizando el valor de la imparcialidad dentro del circuito de propagación de la noticia: “El periódico más leído de la capital levantó ese inmenso murmullo que acompaña a los escándalos, cuyo punto inicial es el crimen” (280). ${ }^{11}$

Un régimen de visibilidad espectacular, es decir susceptible a la ilusión y al consumo de imágenes, es el que caracteriza la cobertura de Rebolledo, el repórter, a través de la inserción de elementos no lingüísticos, como el mapa de la escena del delito, la fragmentación de la anécdota a través de encabezados efectistas y, sobre todo, de la reiteración del crimen como espectáculo (276-77). De su pluma sale el siguiente retrato de Remedios: "Su aire espantaba: lívida, convulsa, sollozante y casi desnuda, parecía la sombra de Macbeth” (276). Rebolledo es el fisgón número uno de la era Porfiriana, como bien destaca Emilio Rabasa en su novela El cuarto poder (1888) al presentar el retrato del típico repórter: "Va a los talleres, entra en las fábricas ... visita las cárceles, frecuenta las iglesias y las cantinas, escucha en las antesalas ministeriales, come en los banquetes de los solemnes y goza de los almuercitos en los barrios pobres” (Toussaint 59). El repórter, como la prostituta, cruza las fronteras de la ciudad y recorre sus espacios proscritos para hacerlos públicos. ${ }^{12}$ En La Rumba, Rebolledo no es sólo el repórter, sino el apuntador del narrador: lo introduce a la cárcel de Belén y lo acompaña durante el juicio, susurrando que en esa obra todos ganan mirando a Remedios.

Tal vez Rebolledo no sólo le sirva de apuntador al irónico de Micrós, sino también al plañidero de Gamboa y al agrio taxonomista de Roumagnac. Este último inicia su diagnóstico reconociendo que María ya no es perceptible sino a través de mediaciones culturales: "Con el sujeto de esta observación vamos a salir de la riña callejera y entramos en el campo de esos criminales, que con Ferri tendríamos que llamar pasionales, y con Laurent, degenerados” (104). Roumagnac fija la mirada en un referente igualmente fijo, el cuerpo vigilado y diagnosticado de María; no obstante, da cabida para que se infiltre otra mirada, la del espectador, al percatarse de que "en ella hay algo de lo que los franceses llaman con su término intraducible, pose ... el inexorable dominio de la coquetería femenil” (105).

${ }^{11}$ Speckman señala, en cuanto a la explicación del crimen en el Porfiriato, que mientras en el periodismo moderno prevalecía un criterio determinista, en el popular proliferaban las explicaciones sobrenaturales y pasionales. No obstante, pese a las distancias ideológicas, ambos estaban dentro de los límites de la hegemonía del régimen, de aquí que Frank considere el periodismo de Vanegas Arrollo una "subcultura" y no una "contracultura" (10).

${ }^{12}$ La comparación de la prensa noticiosa con la prostitución era común en la época. Gutiérrez Nájera comentaba al respecto: "la prensa se prostituye y deja de ser la matrona augusta de la Roma honrada para convertirse en una miserable barragana” (Speckman). 
Federico Gamboa no tiene reparos para no despreciar las técnicas de El Noticioso satirizadas por Micrós. Al contrario, las incorpora a la novela como una estrategia de lectura. El efecto de esta lectura está precisamente en la paradójica diversión ocasionada por un drama: el lector se conduele de Santa, después de haber gozado, vouyeurísticamente de su cuerpo, “cuando la bata se le deslizó y ... una de sus axilas puso al descubierto, por un segundo, una mancha de vello negro, negro ...” (730). El mecanismo de este efecto es deducido por el propio Gamboa, durante el juicio por el que pasa la protagonista de su novela:

... mientras más podamos contemplar a un infeliz solo contra todos ... más nos regocijamos de sólo ser espectadores .... En los abismos de aquella alma, hemos visto los abismos de la nuestra ... pero aquella alma es una vencida y nosotros podemos retirarnos de la diversión al acabar el drama ... ¡hasta podemos condolernos en voz muy alta de la suerte del condenado! (859)

Es curioso que las estrategias de extrañamiento ${ }^{13}$ de Micrós no hayan evitado que sus primeros lectores en las entregas de El Nacional hayan tomado el juicio de Remedios como la crónica de un acontecimiento real (Millán XVII), y es que los límites entre ficción y realidad en materia de crimen no eran del todo claros. Prueba de ello es que la cobertura de los crímenes pasionales perpetrados por mujeres en la prensa popular era mucho mayor que los que realmente acontecían (Frank 19). Inevitablemente, el narrador de La Rumba también se hace cómplice de lo real, pero de lo real como el espectáculo ocasionado por un drama. De los jueces de Remedios, dice este emocionado narrador, "no había uno solo que bajara al fondo de su corazón de mujer” (265).

Patrick Frank interpreta la popularidad de estas representaciones del crimen como espectáculo durante el Porfiriato con una explicación muy similar a la que daba Gamboa: permiten, desde un lugar seguro, imaginarnos a nosotros mismos en situaciones límite (20). Imaginar lo que está del otro lado del límite desde una posición segura, es mostrar el límite de lo representado: detrás de la máscara científica que cuantifica el cuerpo de Villa y de la sensacionalista que viste y desviste el de Remedios y el de Santa, está el cadáver de Esperanza Gutiérrez.

\section{LA QUE MUERE POR SEGUNDA VEZ}

El cadáver de Esperanza yacía en la morgue del hospital Juárez cuando Federico Gamboa recibió la noticia de su muerte por parte de su amigo, el escultor Jesús Contreras. La noche anterior, ambos habían estado en el mismo baile de máscaras, donde Villa y Gutiérrez habían tenido su último altercado público. Gamboa se aterra al pensar en las amonestaciones que su incursión noctámbula a los bajos fondos pudiera ocasionarle; el público podría confundir la figura del intelectual orgánico del Porfiriato con el de la mismísima prostituta: “el aparecer de mi nombre en los diarios ... que la gente de buena conciencia ponga el grito en el cielo y a mí me pongan en disponibilidad ... Me miro

\footnotetext{
${ }^{13}$ Uso el término en el sentido formalista.
} 
envuelto en una averiguación criminal fisgona e implacable” (Diario II 12). No obstante, así como Micrós se atreve a espiar los sombríos interiores de la cárcel de Belén al lado del repórter, así Gamboa, animado por Contreras, soborna al cuidador de la morgue para constatar la muerte de Esperanza. En su diario, el escritor presenta una descripción del cadáver como mera materia en proceso de descomposición, abyecta, sin aura y también sin Eros:

\footnotetext{
... la Malagueña, en desnudez absoluta sin tentaciones ... no aparté mis ojos ... mirando cómo las moscas ... de olores sospechosos y de sangres antiguas ... revoloteaban por el cuerpo desnudo e indefenso; mirando sus carnes, ayer no más complacientes y sedeñas, y hoy rígidas, en descomposición palpable, en camino de los gusanos que han de devorarnos a todos ... Atraíame, fatídicamente, la cicatriz de su ojo izquierdo ... sobre la que caían, revueltos, los cabellos rubios ... (13-14)
}

La inclusión de Gamboa y Contreras en el marco de esta descripción es digna de citar porque ilustra el fracaso del artista voyeur para obliterar la amenaza que impone el cadáver de la prostituta mediante la sublimación del arte. Dos acciones paralelas se suceden ante los ojos de Gamboa; una apunta hacia el proceso de creación (Contreras bosqueja en una hoja de papel el cadáver de Esperanza), mientras que la otra interrumpe este proceso mediante una alusión a una lectura de lo literario profanadora del cadáver: el empleado que les libró la entrada le cuenta a Gamboa que ha leído su novela ¡Vendía Cerillos!, paralelamente fuma un cigarrillo "que al fin se le concluyó entre los dedos amarillentos. Y con una incuria espantosa por sincera, arrojó la colilla baboseada al charquerón de sangre semicoagulada ...” (14).

Para poder asociar la representación del cadáver de Esperanza con la de Santa, recurrimos a Elizabeth Bronfen quien, en su análisis de las imágenes del pintor GodéDarel, comenta sobre el proceso que va de la experiencia de descomposición a la composición de esta experiencia. El cuerpo en descomposición, señala Bronfen, debe ser enterrado una segunda vez: "clearly severed from the living and firmly replaced by a stable image/sign of that body, in the form of funerary sculptures, portraits, or gravestones” (46). En Santa se produce una alegoría a través de la cual se canjean los cuerpos por las almas y los cadáveres por las esculturas. ${ }^{14}$

Muerta desde la primera página de la novela, la protagonista demanda inmortalidad al escultor Jesús Contreras, el mismo que había bosquejado el cadáver de Esperanza Gutiérrez al lado de Gamboa. En la dedicatoria a Contreras, Gamboa pone, en la boca de Santa, la siguiente plegaria: “Acógeme tú y resucítame ¿qué te cuesta ...? ¿No has acogido tanto barro, y en él infundido, no has alcanzado que lo aplaudan y lo admiren?” (717). La resurrección de Santa en escultura es el triunfo del artista en duelo. De aquí que la novela

\footnotetext{
${ }^{14}$ Franco señala que, al hacer público su diario, Gamboa “masculiniza” la escritura que generalmente se asociaba al espacio privado y a la domesticidad femenina. El gesto público que Gamboa hace con esta “confesión” es, según Franco, un gesto conservador al afirmar valores tradicionales: el escritor paga su pecado sexual (su incursión a los bajos fondos) al contemplar la muerte de Esperanza (9697). Nuestra lectura pretende destacar el hecho de que, en la ideología letrada, es la novela, y no el diario, el lugar para sublimar la experiencia a través del arte.
} 
proponga una estetización de lo social: una bella mujer debe morir para producir una obra de arte, una obra de arte emerge a costa de la muerte de una bella mujer (Bronfen 73). No es de sorprender que Contreras, uno de los escultores más celebrados del Porfiriato, haya estado íntimamente ligado al círculo decadentista de la Revista Moderna. ${ }^{15}$

Además de una lectura gratificante en el terreno del arte, Santa puede leerse de manera didáctica: la historia de la prostituta redimida de los modelos bíblicos de María Magdalena y Santa María Egipciaca (Ordiz 38-40), cuya expiación en el terreno religioso es posible únicamente en la muerte. Santa, señala José Emilio Pacheco, “es un cautionary tale, como Caperucita Roja previene a las muchachas contra la seducción y a los jóvenes contra la prostitución” (XXI). También es posible proponer una lectura triste de una novela "casta” sólo a sabiendas de que Santa ya estaba muerta desde la primera página. ${ }^{16}$ Con el cadáver de Santa, Gamboa reconfiguró los bajos fondos citadinos de manera sentimental, levantó su copa y brindó por el porvenir de la muerta y de su ciudad.

No obstante, hay otra manera de leer esta necrología; la trayectoria de Santa hacia su muerte es también una conspiración: matemos a Santa antes de que nos alcance su muerte, ese fantasma que pesa sobre Gamboa, el del proyecto civilizador que devora todo y a todos sin retribuciones. La amenaza de esta muerte radica en lo que Theodor Adorno percibía en Lulú, protagonista de la ópera inconclusa de Alan Berg: “... she dredges up what has been suppressed, looks it in the eye, makes it conscious, and brings it to justice by making herself its equal; a higher court, before which the appeal of the civilizing trial must take place “(131). Con la segunda muerte de Santa, Gamboa suprime la peligrosa rebelión de su protagonista al traducirla en una historia sentimental. Matemos a Santa, desde la primera página, para que su ruina se llene de nostalgia.

\section{CRónica de una muerte anUnCiada}

Como la de Santiago Nasar, la muerte de Santa es una muerte anunciada. Se presiente en cada capítulo y se declara desde el primero, durante su noche inaugural en el burdel cuando el cliente le pregunta de improviso: “¿qué quieres que te regale cuando te mueras?” (735). La pregunta sobrecoge, no sólo a Santa y a los escuchas, sino también a los lectores, a quienes el narrador incluye en el "nosotros" al concluir el párrafo con una lapidaria reflexión: "los cuatro callaron, cual si de veras la muerte esté acechándonos, al alcance del labio que la nombra” (735). Bronfen supone que la representación de la muerte conduce a la inhibición de su conocimiento real, precisamente porque en el arte, la muerte ocurre como imagen en un cuerpo ajeno, muchas veces femenino (XI). En la pregunta del cliente

\footnotetext{
${ }^{15}$ Sobre el círculo decadente de la Revista Moderna véase Campos. Contreras decora los homenajes del Duque Job en la Revista Azul y esculpe la tumba de Julio Ruelas, cuyas ilustraciones le dieron a la Revista Moderna un sello indiscutiblemente fin-de-siècle. El friso rueliano más reproducido es del cuerpo desnudo y yerto de una mujer estrangulada por una serpiente.

${ }^{16}$ En la dedicatoria a Contreras, Gamboa incorpora la frase que precede a la Fille Elisa: "Ce livre, j'ai la conscience de l'avoir fait austère et chaste, sans que jamais la page échappée à la nature délicate et brulante de mon sujet, apporte autre chose à l'esprit de mon lecteur qu'une méditation triste” (717).
} 
a Santa, se infiere que el cuerpo de la prostituta es una proyección de la propia muerte. "Nosotras”, alecciona Elvira a Santa esa primera noche, “sabemos muy distinto, picamos, en ocasiones hasta envenenamos” (729). El deseo por el cuerpo de Santa es la otra cara de su muerte, límite y clímax de la fábula, evento final anunciado desde el principio y proyectado en el espacio geográfico y social. ${ }^{17}$

Entre Chimalistac, el pueblo oriundo de Santa, y la ciudad de México se localiza el Pedregal de San Ángel. Como toda frontera narrativa, donde, al decir de Peter Brooks los comienzos son seleccionados por y en favor de los finales (93), este lindero de leyendas erráticas ${ }^{18}$ es escenario de la menstruación y la consecuente desfloración de Santa, y es ahí donde también se preludia su muerte. Con las lágrimas y la sangre de Santa, Gamboa insinúa su afinidad con una visión contradictoria de la naturaleza femenina, heredada tal vez de las lecturas de Jules Michelet y Joseph Proudhon vía Émile Zolá: el ciclo menstrual de la mujer determina su papel social como maternal y dependiente; su función principal al lado del esposo es unirlo al ritmo de la vida eterna, no obstante, la mujer es un violento abismo en este ritmo que simultáneamente sostiene. Su sangre está enferma. Su afrenta es borrar la diferenciación de sexos arrastrando al hombre a la muerte. ${ }^{19}$ Por ello, al conducir a su seductor de la mano por el puente del río Magdalena en el Pedregal, Santa debe amenazarlo de muerte con la suya propia: “A la mitad del inseguro tronco, Santa se detuvo y ... dijo: - ¡Marcelino, júrame otra vez ...que suceda lo que suceda no has de abandonarme, si no, me tiro!. E hizo ademán de soltarlo. -Por mi alma te lo juro, Santa, no seas loca, que nos caemos (751).”

La afrenta de Santa de arrastrar al hombre a la muerte con la indiferenciación de los sexos, es también la de Villa en el texto de Roumagnac. En la cárcel, ésta le confiesa al criminólogo que no era a Esperanza, sino a Salvador a quien quiso dar muerte: "Muchas veces cuando me lo quedaba viendo, pensaba mil y mil veces en matarle” (114). La ambivalente sexualidad femenina es esa región pantanosa del inconsciente que, al repercutir en la sociedad, se vuelve política (Adorno 133).

\section{NeCrología del ESPACiO NACiOnAL}

En su estudio Foundational Fictions Doris Sommer destaca que en El Zarco, la alegoría nacional de Ignacio Manuel Altamirano, es Eros, y no Thanatos, el edificador del espacio nacional con las nupcias del indio Nicolás y la mestiza Pilar. Este espacio es Yautepec, sinécdoque del país, un paraíso donde los conflictos raciales y regionales han sido resueltos. Para el año de la aparición de El Zarco (terminada en 1888 y publicada

\footnotetext{
${ }^{17}$ Los argumentos de Peter Brooks (toda trama es necrológica) y de Bronfen (la muerte como proyección en el cuerpo femenino) se relacionan con los de Walter Benjamin, quien señalaba que "la muerte es la sanción de todo lo que el narrador puede referir y ella es quien le presta autoridad" (122). Con la interrelación de Eros y Thanatos en la psique, Sigmund Freud (Beyond the Pleasure Principle) también está detrás de estas interpretaciones.

${ }^{18}$ Sobre los orígenes, la topografía, la flora y el capital simbólico del Pedregal durante el Porfiriato, consúltese Carrillo Trueba (40-50, 76-90 y 152-53).

${ }^{19}$ Sobre las teorías de Michelet y Proudhon en la narrativa de Zolá, consultar Bernheimer (204-209). El propio Gamboa articula estas ideas en Santa (843).
} 
póstumamente en 1901), Micrós ya había presentado en La Rumba, otra versión del espacio mexicano: la ciudad con sus abismos sociales en contigüidad geográfica. Durante el Porfiriato, los límites internos y externos de la capital se volvieron inestables, principalmente debido a que los pobres también habitaron la ciudad respetable, pese a que la policía no se cansaba de demarcar las fronteras sociales de la capital, particularmente en el semicírculo que rodeaba al Zócalo y a la Alameda (Piccato 47). El tema de la novela de Micrós, el de la caída de Remedios, está asociado a la representación de estos entornos peligrosos y amenazantes dada su proximidad, como el barrio de la protagonista en donde “flotaban cadáveres de animales ... y zapatos boquiabiertos” (189).

En Santa, también se pone de manifiesto esta estratificación de espacios en tensión, así como las paradojas de su in/visibilidad, principalmente en torno a la prostitución. Por ejemplo, el texto omite la exacta ubicación del burdel de Elvira, tal vez porque, inscrito dentro del primer cuadro citadino, sea de todos conocido aunque de pocos aceptado. ${ }^{20}$ Por su parte, Santa, dueña y señora de los bajos fondos, evade la laboriosa ciudad matutina, atisbando el exterior a través de su ventana, en la alcoba o en el coche. Para Santa, el exterior es una amenaza: ahí está expuesta a la sanción pública.

Difícil es concebir tales espacios como alegorías de lo nacional. Sin embargo, pese al tema, el de la sociabilidad instaurada por la prostitución, límite de lo que la novela nacional podría abarcar, Santa puede considerarse un sociotexto nacional que ha perdurado por encima de Micrós, de Roumagnac y del mismo Gamboa. Tan sólo cotejando sus tirajes e innumerables reimpresiones, es válido afirmar con Pacheco (XVI) que la novela se continúa leyendo fuera de las aulas y que su heroína se traslada al cine y a las reuniones de familia con las canciones del "Flaco de Oro", Agustín Lara. Tal vez parte de esta pervivencia radique en que, al enfrentar la ciudad modernizada con su pasado, Gamboa haya configurado una retórica del desastre pero sistemáticamente nostálgica. ${ }^{21}$ Esta retórica está estrechamente vinculada con la trama, la de la trayectoria circular de Santa que regresa a su origen como cadáver.

\footnotetext{
${ }^{20}$ Una de las estrategias del reglamentarismo francés en torno a la prostitución era la de someter a la prostituta a un régimen de invisibilidad a través de la regulación de su disponibilidad (Bernheimer 16). Tal estrategia también figura en el Código de Sanidad mexicano concerniente a la prostitución y vigente a principios de siglo: "No tendrán los burdeles señal alguna exterior que indique lo que son" (en Lara y Pardo 63). No obstante, en 1908, Luis Lara y Pardo, abrumado por la omnipresencia del "parásito" de la prostitución que se propagaba como por "contagio" pese a las medidas disciplinarias (29), sospechaba lo que Bernheimer expone en su deconstrucción de la lógica del higienista francés Parent-Duchatelet: el lado clandestino de la prostitución, con sus estrategias de camuflaje, frustra la autoridad policíaca que busca traducirla en saber, ocasionando que el discurso disciplinario sea definido por la arbitrariedad misma (Bernheimer 27). De aquí que el mexicano se declare en contra de la reglamentación, dada su futilidad, señalando que "todo México, desde los ancianos más morigerados hasta las doncellas más castas, saben perfectamente cuáles son los burdeles y, naturalmente, lo que significan" (72).

${ }^{21}$ Julio Ramos da el ejemplo de la novela Apariencias de Gamboa y concluye que en gran parte de la literatura latinoamericana escrita a partir de José Martí, el pasado de la ciudad se reformula con el fin de otorgar un aspecto compensatorio a las zonas excluidas o aplastadas por la modernización (122).
} 
Con la lectura de otra de sus novelas, Reconquista, se esclarece la relación que Gamboa establece entre Santa y su ciudad. El protagonista, un pintor viudo llamado Salvador, complica su deber de padre de familia ante una obsesiva necesidad de recorrer la ciudad lasciva en busca de un cuadro para su estilo. El objeto del deseo de Salvador es el cuerpo de la ciudad, un cuerpo personificado en mujer, enferma y prostituida, como Santa (964). Paradójicamente, el cuadro de Salvador debe ser enmarcado por la anulación del deseo que lo produce. Para recuperar "el alma de la ciudad”, es necesario conspirar contra su cuerpo “ rugoso de años, crímenes y vicios” (977). El retorno de Salvador a la ciudad después de su descenso moral es posible solamente cuando el deseo ha sido disfrazado de puro sentimiento; solamente entonces el cuadro puede adquirir "forma y el pueblo redención ...", un pueblo "con el que Salvador simpatizaba no obstante sus repugnancias de esteta hacia lo feo y lo sucio" (966). El pueblo "simpático" es el que ha muerto: ha dejado de constituir una amenaza política al hacerse disponible como icono de identidad para reconstruir la ciudadanía en términos culturales. De igual forma, el cuerpo de la ciudad, como el de Santa, vuelve a ser territorializado a través de imágenes nostálgicas que responden a los cambios violentos que en ella se efectuaban. El nombre político de la muerte de Santa es el del espacio que el escritor reclama una vez asentada su destrucción. Tal es el caso de Chimalistac.

Si bien Gamboa constata la accesibilidad geográfica de esta región dada la presencia de la vía ferroviaria, ${ }^{22}$ nótese que en lo narrado, Chimalistac aparece únicamente como recuerdo evocado por Santa en el burdel, y desde el recuerdo se ha tornado inaccesible: Chimalistac es "un punto que ni el lenguaje sabe precisar ... es el misterioso punto invisible, donde, por ejemplo, queda la muerte” (844). La pureza de Santa también está allí, fuera de la geografía urbana porque ha sido demolida por ella misma, con su fábrica de tejidos, "el gigantesco vampiro” que chupa la sangre de sus hermanos, Esteban y Fabián (746).

No obstante, al morir, el cuerpo de la prostituta se mistifica: regresa a este origen impreciso, para descansar en paz con la ceguera de Hipólito por los siglos de los siglos. Hoy día, la ciudad de México ha devorado a Chimalistac; el pueblo se ha convertido en una colonia de aire bohemio y seductor. Con sus nombres, las calles rememoran a Hipólito, el de Santa. Pocos creen que su historia haya sido solamente literatura. La nueva geografía urbana y su pasado se han reconciliado: el campo es ahí sólo una imagen turística dentro de la ciudad, y el desastre social, concentrado en la ambivalencia de la sexualidad de Santa, se ha hecho admisible en la visión nostálgica de subsecuentes generaciones que con "el Flaco de Oro" siguen llorando "la noche del desconsuelo". ${ }^{23}$

De María Villa, "La Chiquita,” poco se sabe y nada se recuerda. Si bien no se ha encontrado documento alguno sobre el desenlace de su vida en el archivo judicial (Buffington y Piccato 416), se dice que dejó la prisión con el pelo encanecido y que probablemente salió antes de cumplir su condena.

\footnotetext{
${ }^{22}$ La guía turística de Emil Riedel de 1892 describe la zona de Chimalistac como el Aranjuez de México dada su flora y sus “idílicas” residencias. La misma guía verifica la cercanía al municipio de San Ángel, a sólo ocho minutos al suroeste de la capital (392).

${ }^{23}$ Palabras de la canción "Santa” (1932) de Agustín Lara.
} 


\section{BibLIOGRAFÍA}

Adorno, Theodor. Alban Berg. Master of the Smallest Link. Juliane Brand y Christopher Hailey, trads. Cambridge: Cambridge University Press, 1991.

Benjamin, Walter. "El narrador". Para una crítica de la violencia y otros ensayos. Iluminaciones IV. Roberto Blatt, trad. Madrid: Taurus, 1991. 111-34.

Berdecio Roberto y Stanley Appelbaum, eds. Posada's Popular Mexican Prints. New York: Dover Publications, Inc., 1972.

Bernheimer, Charles. Figures of Ill Repute. Representing Prostitution in NineteenthCentury France. Durham y Londres: Duke University Press, 1997.

Bronfen, Elizabeth. Over her Dead Body. Death, Feminity and the Aesthetic. New York: Routledge, 1992.

Brooks, Peter. Reading for the Plot. Design and Intention in Narrative. Cambridge, Massachusetts: Harvard University Press, 1992.

Brunner, Jerome. Acts of Meaning. Cambridge: Harvard University Press, 1990. The Culture of Education. Cambridge: Harvard University Press, 1990.

Buffington, Robert y Pablo Piccato. "Tales of Two Women: The Narrative Construal of Porfirian Reality”. The Americas. A Quarterly Review of Inter-American Cultural History 55/3 (enero 1999): 391-424.

Carrillo Trueba, César. El Pedregal de San Ángel. México: Universidad Nacional Autónoma de México, 1995.

Campo, Ángel de. Ocios y apuntes y La Rumba. María del Carmen Millán, ed. México: Porrúa, 1969.

Campos, Rubén M. El Bar. La vida literaria en México en 1900. México: Universidad Nacional Autónoma de México, 1996.

Dijkastra, Bram. Idols of Perversity: Fantasies of Feminine Evil in Fin-de-Siècle Culture. New York: Oxford University Press, 1986

Frank, Patrick. Posada's Broadsheets. Mexican Popular Imagery 1890-1910. Albuquerque: University of New Mexico Press, 1998.

Franco, Jean. Plotting Women. Gender and Representation in Mexico. New York: Columbia University Press, 1989.

Gamboa, Federico. Mi diario II (1897-1900). México: Consejo Nacional para la Cultura y las Artes, 1995

Mi diario III (1901-1904). México: Consejo Nacional para la Cultura y las Artes, 1995.

Reconquista. Novelas. Prólogo de Francisco Monterde. México: Fondo de Cultura Económica, 1965. 923-1101.

Santa. Novelas. Prólogo de Francisco Monterde. México: Fondo de Cultura Económica, 1965. 719-922.

Giddens, Anthony. The consequences of Modernity. Stanford: Stanford University Press, 1990.

Guerrero, Julio. La génesis del crimen en México. Estudio de psiquiatría social. [1901]. México: Consejo Nacional para la Cultura y las Artes, 1996. 
Guy, Donna J. Sex and Danger in Buenos Aires. Prostitution, Family, and Nation in Argentina. Lincoln: University of Nebraska Press, 1991.

Lara y Pardo, Luis. La prostitución en México. México: Librería de la viuda de Charles Bouret, 1908.

Ludmer, Josefina. “Mujeres que matan”. Revista Iberoamericana 176-177 (julio-diciembre 1996): 781-99.

"Una lectura de Santa". Literatura Mexicana del otro fin de siglo. Rafael Olea Franco, ed. México: El Colegio de México, 2001. 206-12.

Millán, María del Carmen. Prólogo. Ocio y apuntes y La Rumba. Ángel de Campo México: Porrúa, 1969. XI-XXIII.

Ordiz, Javier. Introducción. Santa. Federico Gamboa. Madrid: Cátedra, 2002.

Pacheco, José Emilio. Introducción. Mi Diario I(1892/1896). Federico Gamboa. México: Consejo Nacional para la Cultura y las Artes, 1995

Piccato Pablo. City of Suspects. Crime in Mexico City. 1900-1931. Durham y Londres: Duke University Press, 2001.

Ramos, Julio. Desencuentros de la modernidad en América Latina: literatura y política en el siglo XIX. México: Fondo de Cultura Económica. 1989.

Riedel, Emil. Practical Guide of the City and Valley of Mexico. Mexico: Epstein. Publisher and Editor of the Germania, 1892.

Roumagnac, Carlos. Los criminales en México. Ensayo de psicología criminal. México: Tipografía del Fénix, 1904.

Showalter, Elaine. Sexual Anarchy: Gender and Culture at The Fin de Siècle. New York: Viking, 1990.

Sommer, Doris. Foundational Fictions. The National Romances of Latin America. Berkeley: University of California Press, 1984.

Speckman Elisa. "La prensa, los periodistas y los lectores (Ciudad de México, 19031911”. Belem Clark de Lara y Fernando Curiel Defossé, eds. Revista Moderna de México (1903-1911). Vol. II Contexto. Instituto de Investigaciones Filológicas. (Colecciones Especiales 27). México: Universidad Nacional Autónoma de México, 2002. 107-142.

Toussaint Alcaraz, Florence. Escenario de la prensa en el Porfiriato. Fundación Manuel Buen Día. Colima; Universidad de Colima, 1989.

Tyler, Ron, ed. Posada's Mexico. Washington: Library of Congress, 1979. 